\title{
Expression of hBD-2 induced by 23-valent pneumococcal polysaccharide vaccine, Haemophilus influenzae type b vaccine and split influenza virus vaccine
}

\author{
ZHENWEI SHEN $^{1}$ and HAN LEI ${ }^{2}$ \\ Departments of ${ }^{1}$ Intensive Care Unit and ${ }^{2}$ Respiratory Medicine, Eastern Hospital, \\ Tongji University, Shanghai 200120, P.R. China
}

Received January 4, 2012; Accepted July 18, 2012

DOI: $10.3892 / \mathrm{mmr} .2012 .1005$

\begin{abstract}
Human $\beta$-defensin-2 (hBD-2) is an antimicrobial peptide with high activity and broad spectrum activity. hBD-2 expression may be highly elevated by microorganisms and inflammation. We reported that the majority of common vaccines used, including 23 -valent pneumococcal polysaccharide vaccine, Haemophilus influenzae type $b$ vaccine and split influenza virus vaccine, could induce the expression of hBD-2 in epithelial cells. Among them, the 23-valent pneumococcal polysaccharide vaccine was effective at a lower concentration $(0.5 \mu \mathrm{g} / \mathrm{ml})$, while Haemophilus influenzae type $\mathrm{b}$ vaccine and split influenza virus vaccine were effective at the concentration of $1 \mu \mathrm{g} / \mathrm{ml}$. However, bacteriostatic experiments revealed that the split influenza virus vaccine was capable of inducing the highest antimicrobial activity. The medium of the 23-valent pneumococcal polysaccharide vaccine treatment group had a higher antimicrobial activity than the medium of the Haemophilus influenzae type $b$ vaccine treatment group. The transcriptional regulator of hBD-2, that is, the NF- $\mathrm{kB}$ subunit, had a high level of activity, while the normal epithelial cells showed barely detectable activity, indicating that these vaccines have potential for clinical application.
\end{abstract}

\section{Introduction}

Human defensins are a group of antimicrobial peptides that defend hosts against bacterial, fungal and viral infections (1). Human $\beta$-defensins (hBDs) are a subfamily of defensins distributed at various mucosal surfaces (2). Although multiple gene duplications were observed in the human genome, only hBD-1, hBD-2, hBD-3 and hBD-4 have been described in detail to date (3). hBD-2 is the first member of the human defensin family that has been observed to be highly induced

Correspondence to: Dr Han Lei, Department of Respiratory Medicine, No. 150, Jimo Road, Pudong New Area, Shanghai 200120, P.R. China

E-mail: shentongji@126.com

Key words: vaccine, human airway epithelial cells, $\beta$-defensin-2 in inflamed epidermal cells, such as airway epithelia and in psoriasis $(4,5)$. Previous studies had demonstrated that hBD-2 had high antimicrobial activity and broad spectrum activity $(6,7)$.

The epithelial surface of the lungs is exposed to a large number of potentially pathogenic microorganisms. Several defence mechanisms are required to protect against infection. The production of antimicrobial peptides is one of the most important and evolutionarily conserved mechanisms. hBD-1 and hBD-2 were found to be locally expressed in the lung. Previous studies indicated that hBD-2 expression was induced by inflammation, whereas hBD-1 serves as a defense mechanism in the absence of inflammation $(5,8)$. Furthermore, by measuring the concentration of hBD-2 in the bronchoalveolar lavage fluid of cystic fibrosis patients, the decrease of $\beta$-defensins in advanced lung disease was found to lead to a secondary defect of the local host defense (9). Hence, hBD-2 in the lung is likely to provide an effective shield from microbial infection.

hBD-2 exhibits particularly effective capacity against Gram-negative bacteria and certain fungi $(7,10)$. Gram-negative bacteria, receiving notable concern in recent years, show the feature of using a plethora of mechanisms against antibiotics, which are due to gene cassettes and integrons $(11,12)$. This feature makes them more resistant to antibiotics. While antibiotic resistance has become an increasing global problem, the discovery and development of new antibiotics has declined (13). Infections due to antibiotic-resistant bacteria cause a major public health dilemma, which may lead to future serious medical and social problems. Moreover, hospital-acquired infections have become a major threat to patient safety, and are associated with prolonged hospital stays, higher healthcare costs and increased mortality (14-16). The emergence of antibiotic-resistant infections mainly caused by Gram-negative bacteria aggravates the situation $(14,15,17,18)$. Thus, in this study, we intend to elevate endogenous hBD-2 protein expression in order to meet the emerging clinical challenge.

Since the discovery of natural antimicrobial peptides, much research has been carried out to improve the innate immune response, including the study of many gene-based therapies (19-24). However, to date, all these methods are under preliminary investigation, and no new clinical application has 

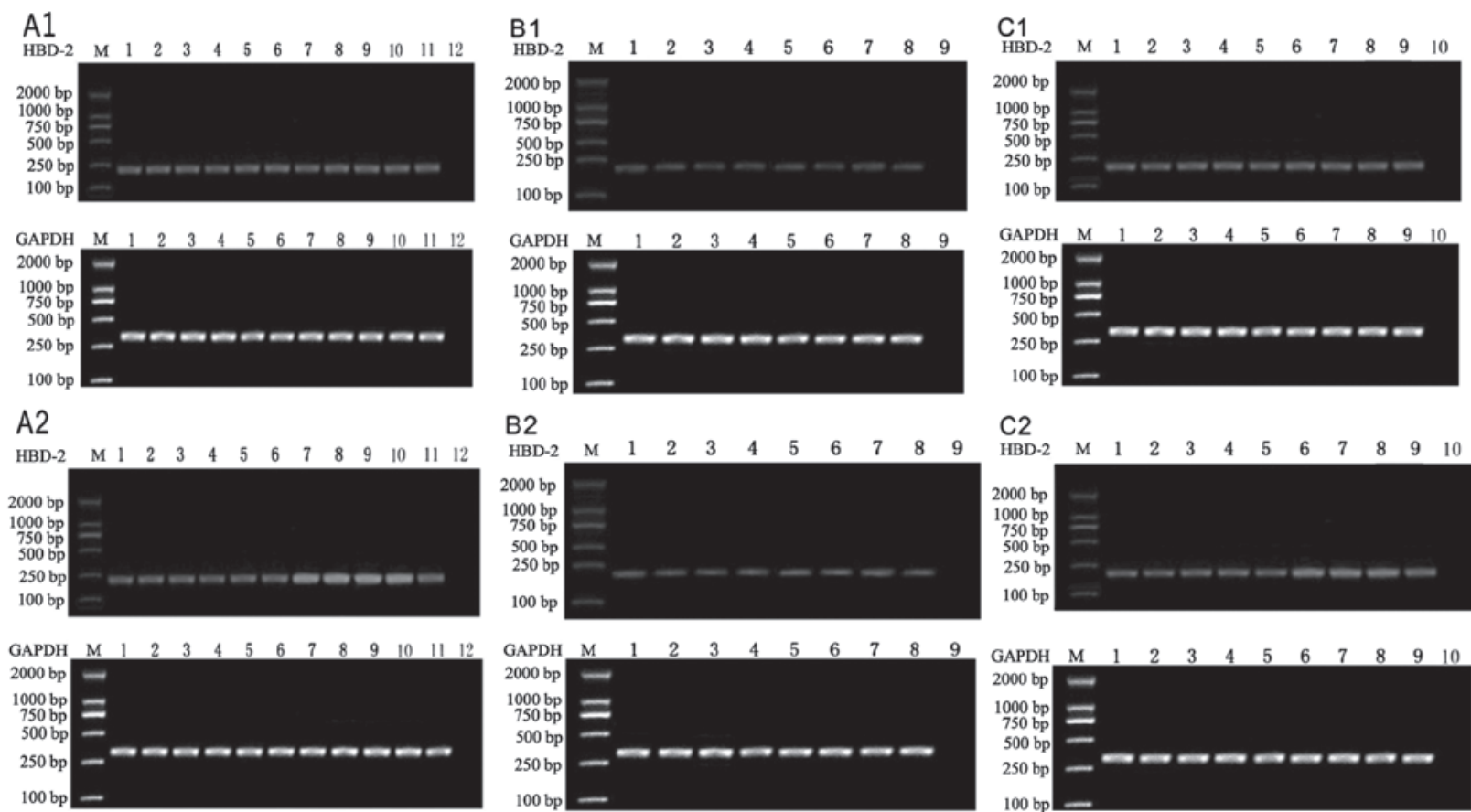

C2

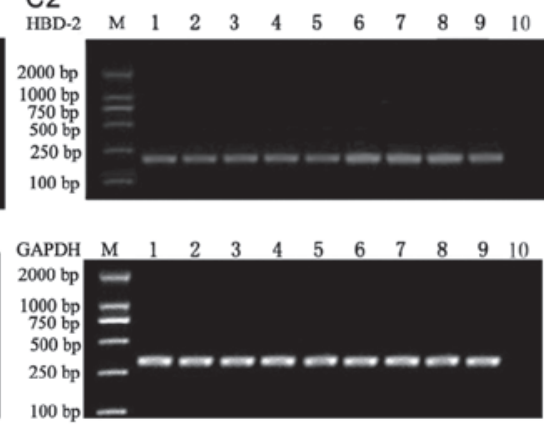

Figure 1. Analysis of mRNA expression for hBD-2 in epithelial cells treated with Streptococcus pneumoniae vaccine for (A1) $6 \mathrm{~h}$ and (A2) $12 \mathrm{~h}, \mathrm{Hemophilus}$ influenzae vaccine for (B1) $6 \mathrm{~h}$ and (B2) $12 \mathrm{~h}$ and influenza virus vaccine for (C1) $6 \mathrm{~h}$ and (C2) $12 \mathrm{~h}$. Lanes 1-10: without the vaccine; 0.00001, 0.00005, 0.0001, $0.005,0.05,0.5,1,2,5 \mu \mathrm{g} / \mathrm{ml}$ of the vaccine; lane 11, ATP; lane 12, PBS; M, marker. hBD-2, human $\beta$-defensin-2.

been proposed. In this study, we found that killed vaccines, including the 23 valent pneumococcal polysaccharide vaccine, Haemophilus influenzae vaccine and split influenza virus vaccine, could serve as potential inducers of hBD-2. We propose that these vaccines, which already have proven biosafety records, may be used as a potential clinical approach.

\section{Materials and methods}

Primary cell culture and treatment. Human bronchial epithelia were surgically resected from patients without lung infection or tumors. The research was approved by the Ethics Committee of Tongji University, China. Primary tissues were digested by $0.125 \%$ trypsin with $0.01 \%$ EDTA, and cultured in Dulbecco's modified Eagle's medium/nutrient mixture F12 supplemented with $10 \%$ fetal bovine serum and $1 \%$ penicillinstreptomycin. For treatment, cells were plated in 6-well plates at a density of $1 \times 10^{5} /$ well. Treatment with 23 -valent pneumococcal polysaccharide vaccine, haemophilus influenzae type $b$ vaccine or split influenza virus vaccine was performed after the cells reached $\sim 80 \%$ confluence. Two independent experiments were performed and each experiment consisted of at least triplicate samples.

RNA extraction and semi-quantitative RT-PCR. Following treatment, cells were lysed with $1 \mathrm{ml}$ of TRIzol reagent. Total RNA was extracted according to manufacturer's instructions and dissolved in $30 \mu 1 \mathrm{H}_{2} \mathrm{O}$ with DEPC. Total RNA $(2 \mu \mathrm{g})$ was used for semi-quantitative RT-PCR according to the manufacturer's instructions. GAPDH was selected as an internal control for normalization. For hBD-2 expression, the primers were designed according to the cDNA sequences (GeneBank accession no. NM_004942.2): the forward primer was 5'-CTT
GTATCTCCTCTTCTCGTTCC-3' and the reverse primer was 5'-TTTCTGAATCCGCATCAGC-3'. For GAPDH expression, the forward primer was 5'-GTCGGTGTGAACGGATTT-3' and the reverse primer was 5'-ACTCCACGACGTACTC AGC-3'. cDNA ( $2 \mu \mathrm{l})$ was amplified for hBD-2 and GAPDH. PCR was performed in a $20-\mu \mathrm{l}$ final volume containing $2 \mu \mathrm{l}$ 10X reaction buffer, $0.2 \mathrm{mM}$ dNTP, $2 \mathrm{mM} \mathrm{MgCl}_{2}$ and 1.5 units TaqDNA polymerase. The cycle numbers that generated approximately half maximal amplification were determined by testing different cycle numbers of amplification for each gene, and were found to be 40 cycles for hBD-2 and 30 cycles for GAPDH. The PCR conditions were $94^{\circ} \mathrm{C}$ for $15 \mathrm{sec}$, annealing at $61^{\circ} \mathrm{C}$ for hBD-2 and $57^{\circ} \mathrm{C}$ for GAPDH for $20 \mathrm{sec}$ and extension at $72^{\circ} \mathrm{C}$ for $30 \mathrm{sec}$. The PCR product $(5 \mu \mathrm{l})$ was checked on a $2.0 \%$ agarose gel and visualized using ethidium bromide staining with UV illumination. The intensity of each band was analyzed using the BioSenSC300 system.

Enzyme-linked immunosorbent assay. The medium was collected at 6 and $12 \mathrm{~h}$ following treatment. After centrifugation at $3000 \mathrm{~g}$ for $20 \mathrm{~min}$, the supernatant samples were removed. The manufacturer's instructions for enzyme-linked immunosorbent assay (ELISA) were followed. Briefly, the microtiter plates were coated by adding $100 \mu \mathrm{l}$ of the samples. After 90 min incubation, the microtiter plates were agitated to remove the samples. Biotin-labeled antibody $(100 \mu \mathrm{l})$ was added and the plates were then incubated at $37^{\circ} \mathrm{C}$ for $60 \mathrm{~min}$. After three washing steps with $0.01 \mathrm{M}$ PBS, the plates were filled with with $100 \mu \mathrm{l}$ avidin-biotin-peroxidase complex at $37^{\circ} \mathrm{C}$ for $30 \mathrm{~min}$. After extensive washing, the immunological reactions were revealed by 30 -min incubation in the dark with $90 \mu 1$ TMB Microwell substrate. TMB stop solution was added to stop the reaction. The optical density results were 
converted into concentrations deduced from a calibration curve.

Electrophoretic mobility shift assay (EMSA). According to the core recognition site of $\mathrm{NF}-\kappa \mathrm{B}$, the following oligonucleotides were synthesized for double-stranded probes: forward (5'-AGT TGA GGG GAC TTT CCC AGG C-3') and reverse (3'-GCC TGG GAA AGT CCC CTC AAC T-5'). The annealed oligonucleotides were labeled with DIG dUTP by terminal transferase. The cellular extracts was incubated at room temperature for $20 \mathrm{~min}$ with $1 \mu \mathrm{g}$ Poly $(\mathrm{dI}-\mathrm{dC})$ in a binding buffer containing $1 \mathrm{X}$ binding buffer, $2.5 \%$ glycerol, $0.05 \%$ NP-40, $100 \mathrm{mM} \mathrm{MgCl}$ and $20 \mathrm{fM}$ biotin end-labeled target DNA. DNA-protein complexes were separated from free DNA by electrophoresis in a non-denaturing polyacrylamide gel at $4^{\circ} \mathrm{C}$ and electrophoretically transferred onto nylon membranes. The membranes were then dried in a drier at $70^{\circ} \mathrm{C}$ for $1 \mathrm{~h}$ and blocked with blocking buffer for $15 \mathrm{~min}$. After extensive washing, the membranes were incubated with substrate equilibration buffer for $5 \mathrm{~min}$; subsequently substrate working solution was added and the samples were incubated for another 5 min. Finally, images of the membranes were captured on film cassette following exposure to X-ray for $20 \mathrm{~min}$.

Bacteriostatic experiment. The concentrated medium of cells treated with 23 valent pneumococcal polysaccharide vaccine, Haemophilus influenzae vaccine and split influenza virus vaccine were collected. The round filter paper was immersed in the medium, PBS and clean medium, respectively. The spread plate method was used to measure the antimicrobial activity.

Measurement of the concentration of $\mathrm{Ca}^{2+}$. Cells were plated in a $15 \times 15-\mathrm{mm}$ culture dish. After the cells reached $\sim 90 \%$ confluence, the medium was replaced with D-Hanks buffer. An appropriate amount of Fluo-3/AM was added into the buffer at a final concentration of 5-10 $\mu \mathrm{mol} / 1$ and incubated with the cells at $37^{\circ} \mathrm{C}$ in a $5 \% \mathrm{CO}_{2}$ atmosphere for $60 \mathrm{~min}$ in the dark. Cells were then washed twice by PBS and once by D-Hanks buffer. Fluorescent images of the cells were visualized in D-Hanks buffer under a laser scanning confocal microscope at an excitation wavelength of $488 \mathrm{~nm}$ and an emission wavelength of $525 \mathrm{~nm}$.

Statistical analyses. Data were presented as the means \pm SD. Statistical analysis was performed using SPSS 11.0.0 (SPSS Inc., Chicago, IL, USA). Data were analyzed by one-way ANOVA followed by Dunnett's multiple comparison test. $\mathrm{P}<0.05$ was considered to indicate a statistically significant difference.

\section{Results}

Expression of hBD-2 mRNA in epithelial cells with various stimuli. To investigate the expression of hBD-2 mRNA in epithelial cells with different vaccine treatments, dose-effect experiments were performed (Fig. 1). As shown in Fig. 2, no marked upregulation was observed following $6 \mathrm{~h}$ of treatment. Another $6 \mathrm{~h}$ later, when the concentration of 23 valent pneumococcal polysaccharide vaccine was above $0.5 \mu \mathrm{g} / \mathrm{ml}$, it enhanced the expression over 1.5-fold. The expression
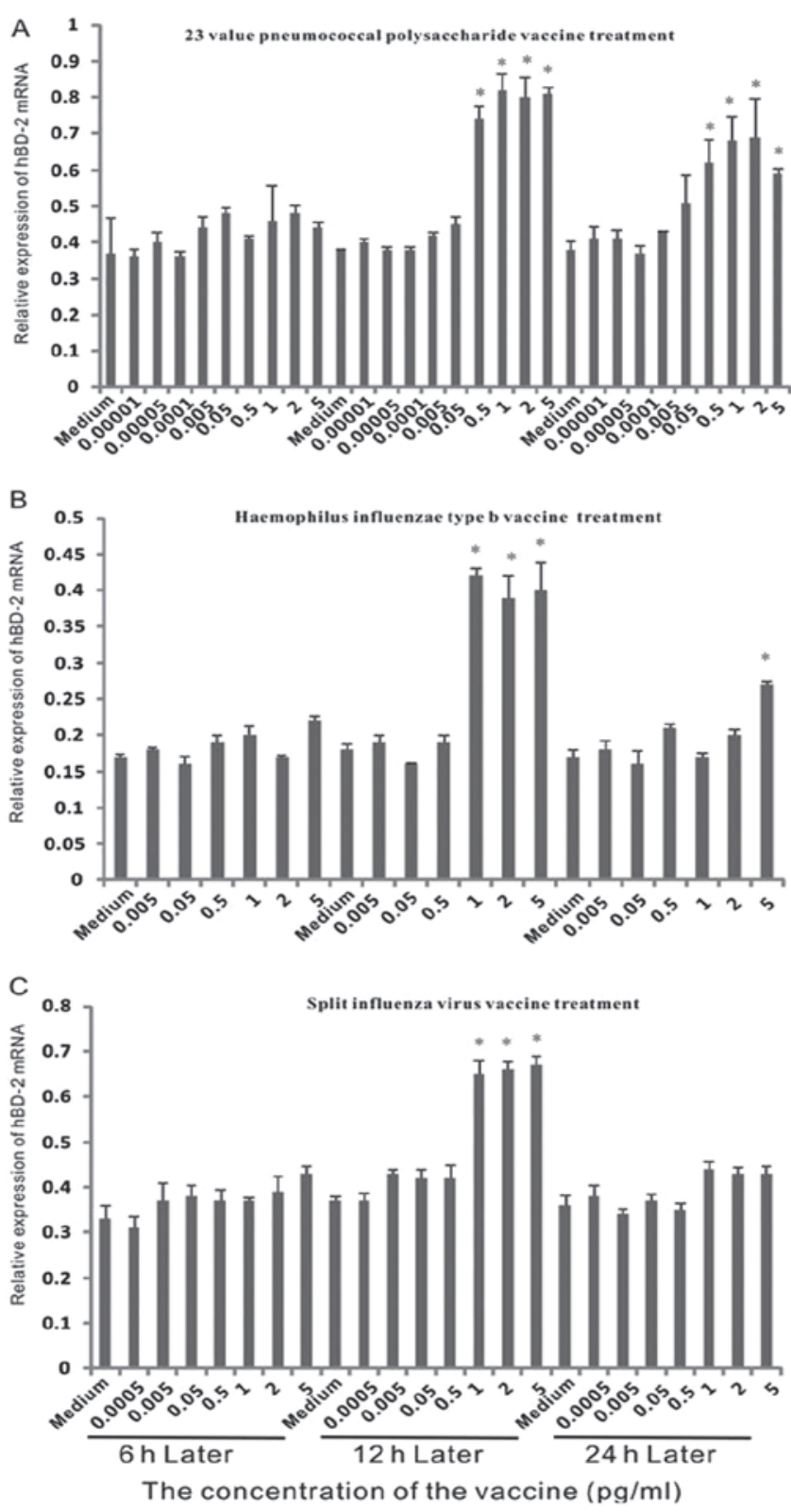

Figure 2. Expression of hBD-2 mRNA in epithelial cells treated with (A) 23 valent pneumococcal polysaccharide vaccine, (B) Haemophilus influenzae type $b$ vaccine and $(C)$ split influenza virus vaccine by semi-quantitative RT-PCR. The results are presented as normalized fold expression with respect to $\beta$-actin levels for the same sample. Cell samples were collected after 6 or $12 \mathrm{~h}$ of incubation with or without the vaccines. Asterisks indicate a significant difference between the non-treatment group and the treatment groups at the same time point $(\mathrm{P}<0.05)$. hBD-2, human $\beta$-defensin- 2 .

exhibited over 2-fold induction when cells were treated with greater than $1 \mu \mathrm{g} / \mathrm{ml}$ Haemophilus influenzae vaccine. For the split influenza virus vaccine, when the concentration was above $1 \mu \mathrm{g} / \mathrm{ml}$, it stimulated the expression by greater than 1.5 -fold.

At $24 \mathrm{~h}$, the expression level of hBD-2 with 23 valent pneumococcal polysaccharide vaccine treatment was lower than at $12 \mathrm{~h}$. In the Haemophilus influenzae vaccine treatment group, a significant difference was only observed at the concentration of $5 \mu \mathrm{g} / \mathrm{ml}$. In the split influenza virus vaccine treatment group, no significant difference was detected. This indicated that the effect of vaccines on hBD-2 expression may be short-term. 

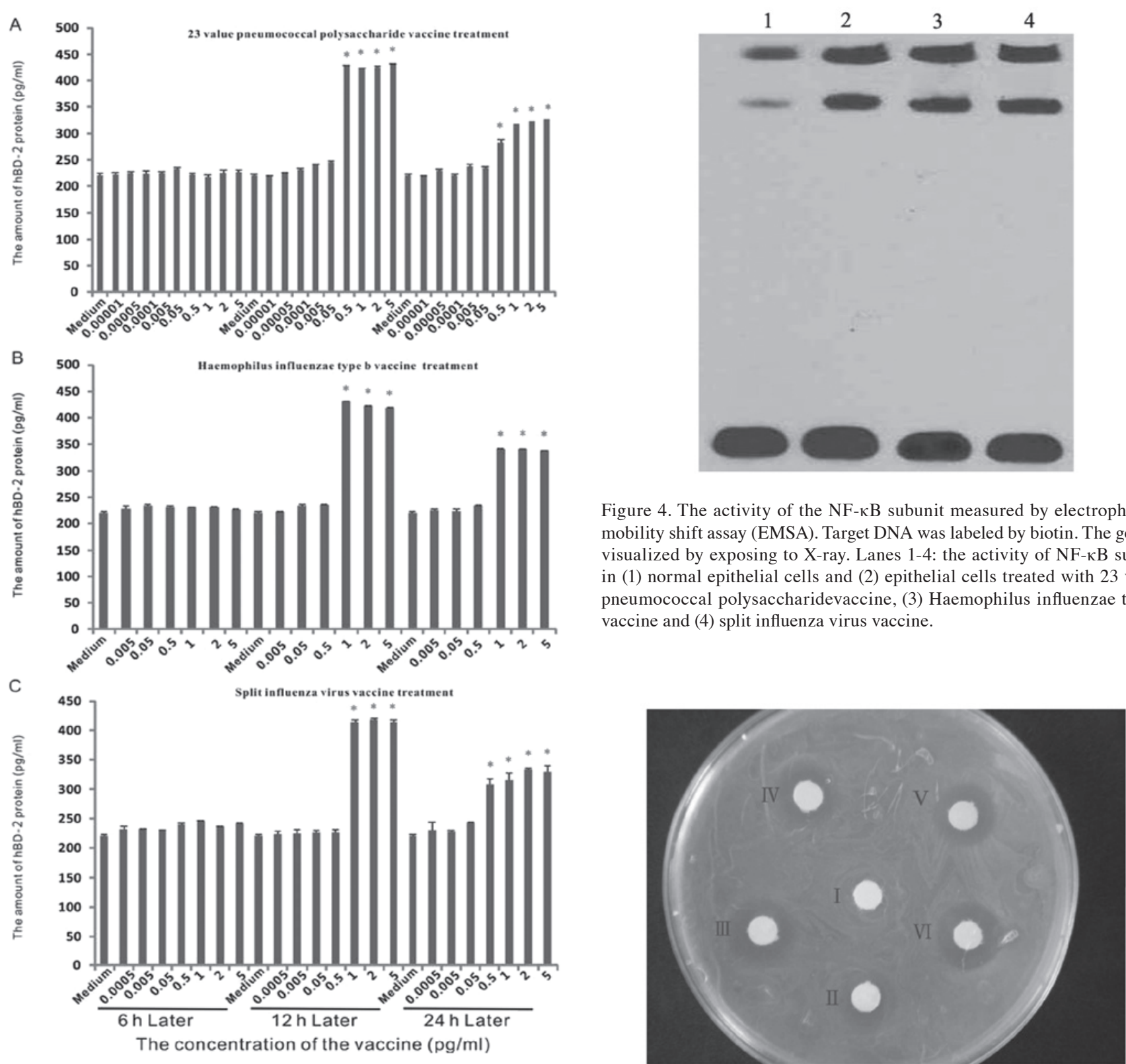

Figure 3. Expression of hBD-2 protein in the medium of the epithelial cells treated with (A) 23 valent pneumococcal polysaccharidevaccine (B) Haemophilus influenzae type b vaccine and (C) split influenza virus vaccine by ELISA. The media of cells with or without treatment was collected after 6 or $12 \mathrm{~h}$ of incubation. Asterisks indicate a significant difference between the non-treatment group and the treatment groups at the same time point $(\mathrm{P}<0.05)$. hBD-2, human $\beta$-defensin- 2 .

Expression of $h B D-2$ protein in epithelial cells with various stimuli. To determine the concentration of protein, we performed ELISA with the medium of the dose-effect experiments mentioned previously (Fig. 3). After the first $6 \mathrm{~h}$, no marked increase of protein occurred. Following $12 \mathrm{~h}$ of treatment, there was a $\sim 2$-fold induction by the 23 valent pneumococcal polysaccharide vaccine with concentrations of above $0.5 \mu \mathrm{g} / \mathrm{ml}$. Similarly, a $\sim 2$-fold induction was observed when the Haemophilus influenzae vaccine or split influenza virus vaccine was used with concentrations above $1 \mu \mathrm{g} / \mathrm{ml}$. At $24 \mathrm{~h}$, the amount of hBD-2 protein was lower than at $12 \mathrm{~h}$, but remained higher than that in the control group.

Figure 5. Bacteriostatic experiment. I, PBS; II, medium; III, ATP; IV, Haemophilus influenzae type b vaccine; V, 23 valent pneumococcal polysaccharidevaccine; VI, split influenza virus vaccine.

$N F-\kappa B$ involved in the signal pathway of vaccine-stimulation. Since NF- $\kappa$ B is a well-known mediator of induction of hBD-2 in epithelial cells, we tested the activity of the NF- $\mathrm{\kappa B}$ subunit in normal epithelial cells and epithelial cells treated with the vaccines by EMSA (Fig. 4). Treatment with vaccines markedly increased the activity of the NF- $\mathrm{KB}$ subunit, while the activity of the NF- $\mathrm{kB}$ subunit was barely detected in normal epithelial cells.

Comparison of antimicrobial ability. To analyze the antimicrobial ability, concentrated medium was used for the bacteriostatic experiment (Fig. 5). The spots of inhibition were not clear for PBS and normal medium. The spot diameter was $12 \mathrm{~mm}$ with medium treated with 23 valent pneumococcal polysaccharide vaccine, $10 \mathrm{~mm}$ with medium treated with 

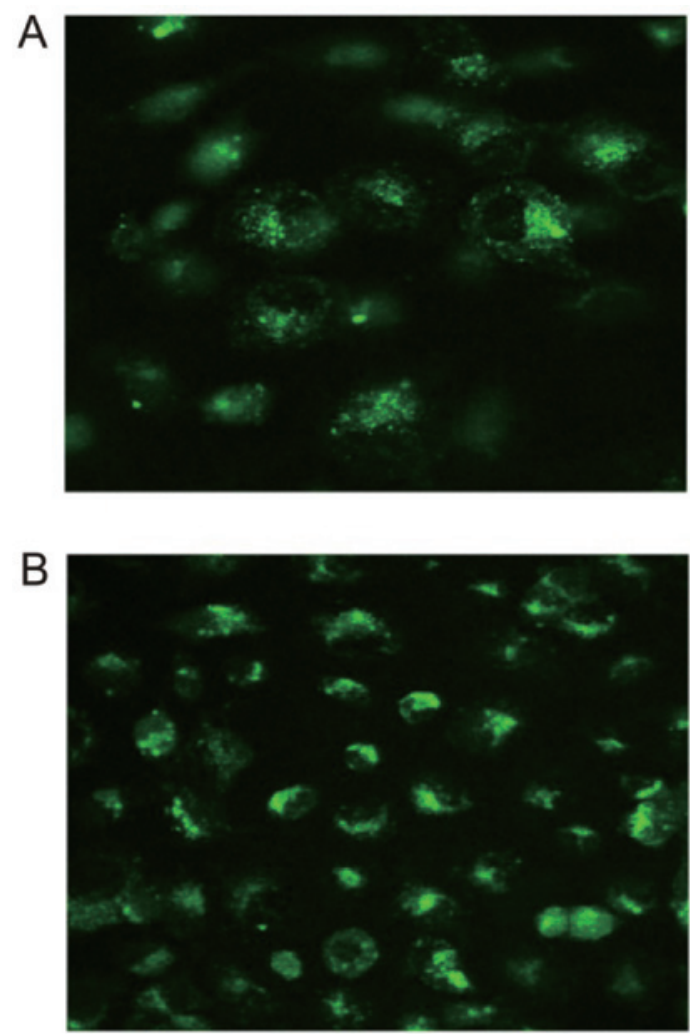

Figure 6. The concentration of $\mathrm{Ca}^{2+}$ in (A) normal epithelial cells and (B) epithelial cells treated with $0.5 \mu \mathrm{g} / \mathrm{ml}$ Streptococcus pneumoniae vaccine for $12 \mathrm{~h}$.

Haemophilus influenzae vaccine and $19 \mathrm{~mm}$ with medium treated with split influenza virus vaccine.

\section{Discussion}

In this study, we have used vaccines, including 23 valent pneumococcal polysaccharide vaccine, Haemophilus influenzae vaccine and influenza virus vaccine, to elevate the expression of hBD-2. The expression level of hBD-2 is markedly low in the absence of inflammation (8). In vivo, the vaccines may significantly induce the expression of hBD-2 within the first $12 \mathrm{~h}$ at an appropriate concentration. After $24 \mathrm{~h}$, the expression of hBD-2 declined, but it remained significantly higher than the control group in the 23 valent pneumococcal polysaccharide vaccine treatment group and in the Haemophilus influenzae vaccine treatment group. This indicated that the effect of vaccines may be short-term.

Several microorganisms are capable of inducing the expression of certain defensins (25-27). Besides microorganisms, LTB4, L12, L23, L27 and certain other immune factors also induce the expression of hBD-2 $(24,28)$. However, using these microorganisms to study the regulation and function in vivo and in vitro often leads to the threat of a biological hazard. Our results showed that vaccines could also serve as inducers of hBD-2, but with improved biosafety, simplicity and inexpensiveness. Hence, vaccines may be an alternative to the use of microorganisms and may facilitate the study of hBD-2.

Functional binding sites for NF- $\kappa \mathrm{B}$ and AP-1 were identified in the promoter of hBD-2 (29-31). Besides these, little was known about the mechanism of induction of hBD-2. Multiple signaling pathways are involved in the inducible expression of hBD-2 (26). Hence, our study set up a biosecure model that facilitates the study of the mechanism of inducible expression in epithelial cells. As the NF- $\kappa \mathrm{B}$ subunit was activated by the vaccines in our model, this indicated that our model could simulate the in vivo defense mechanism against microorganisms. Moreover, our preliminary results showed that vaccines could increase the concentration of $\mathrm{Ca}^{2+}$ within epithelial cells, which is in line with a previous study that proposes that the increase of $\mathrm{Ca}^{2+}$ is necessary for the activation of NF- $\kappa \mathrm{B}$ (Fig. 6) (32).

During our investigation, the medium of split influenza virus vaccine treatment was revealed to have the highest antimicrobial activity with the least amount of hBD-2. Certain other antimicrobial peptides induced by the specific vaccine may contribute to the variation of the antimicrobial activity. The 23 valent pneumococcal polysaccharide vaccine was more sensitive to stimulating hBD-2 expression. Further research is required to explain the variation in innate immune response to exogenous stimulation.

Although the pharmaceutical industry endeavors to develop effective therapies against Gram-negative bacteria, it is difficult to meet the clinical challenge (33). hBD-2, with high antimicrobial activity against Gram-negative bacteria, is regarded as an approach to solve the problem. Thus, the effectiveness of vaccine-induced hBD-2 should be investigated in future studies.

\section{Acknowledgements}

This study was financially supported by the National Natural Science Foundation of China (No. 30670932), the Social Development Bureau Fund of Shanghai Municipal Pudong New District (No. pw2005A-10) and the Medicine Leading Talent Project Fund of Shanghai Municipal Pudong New District (CX2004004).

\section{References}

1. Lehrer RI: Primate defensins. Nat Rev Microbiol 2: 727-738, 2004.

2. Pazgier M, Hoover DM, Yang D, Lu W and Lubkowski J: Human beta-defensins. Cell Mol Life Sci 63: 1294-1313, 2006.

3. Rodriguez-Jimenez FJ, Krause A, Schulz S, et al: Distribution of new human beta-defensin genes clustered on chromosome 20 in functionally different segments of epididymis. Genomics 81: 175-183, 2003 .

4. Schroder JM and Harder J: Human beta-defensin-2. Int J Biochem Cell Biol 31: 645-651, 1999.

5. Liu L, Wang L, Jia HP, et al: Structure and mapping of the human beta-defensin HBD-2 gene and its expression at sites of inflammation. Gene 222: 237-244, 1998.

6. Hiratsuka T, Nakazato M, Date Y, et al: Identification of human beta-defensin-2 in respiratory tract and plasma and its increase in bacterial pneumonia. Biochem Biophys Res Commun 249: 943-947, 1998.

7. Bals R, Wang X, Wu Z, et al: Human beta-defensin 2 is a saltsensitive peptide antibiotic expressed in human lung. J Clin Invest 102: 874-880, 1998.

8. Singh PK, Jia HP, Wiles K, et al: Production of beta-defensins by human airway epithelia. Proc Natl Acad Sci USA 95: 14961-14966, 1998.

9. Chen CI, Schaller-Bals S, Paul KP, Wahn U and Bals R: Betadefensins and LL-37 in bronchoalveolar lavage fluid of patients with cystic fibrosis. J Cyst Fibros 3: 45-50, 2004.

10. Harder J, Bartels J, Christophers E and Schröder JM: A peptide antibiotic from human skin. Nature 387: 861, 1997. 
11. Hall RM and Collis CM: Antibiotic resistance in gram-negative bacteria: the role of gene cassettes and integrons. Drug Resist Updat 1: 109-119, 1998.

12. Partridge SR: Analysis of antibiotic resistance regions in Gramnegative bacteria. FEMS Microbiol Rev 35: 820-855, 2011.

13. Boucher HW, Talbot GH, Bradley JS, et al: Bad bugs, no drugs: no ESKAPE! An update from the Infectious Diseases Society of America. Clin Infect Dis 48: 1-12, 2009.

14. Slama TG: Gram-negative antibiotic resistance: there is a price to pay. Crit Care 12 (Suppl 4): S4, 2008.

15. Peleg AY and Hooper DC: Hospital-acquired infections due to gram-negative bacteria. N Engl J Med 362: 1804-1813, 2010.

16. Mauldin PD, Salgado CD, Hansen IS, Durup DT and Bosso JA Attributable hospital cost and length of stay associated with health care-associated infections caused by antibiotic-resistant gram-negative bacteria. Antimicrob Agents Chemother 54: $109-115,2010$.

17. Siegel RE: Emerging gram-negative antibiotic resistance: daunting challenges, declining sensitivities, and dire consequences. Respir Care 53: 471-479, 2008.

18. Chopra I, Schofield C, Everett M, et al: Treatment of healthcare-associated infections caused by Gram-negative bacteria: a consensus statement. Lancet Infect Dis 8: 133-139, 2008.

19. Xu B, Dong CY,Zhang F, Lin YM, Wu KF and Ma XT: Synergistic antileukemia effect of combinational gene therapy using murine beta-defensin 2 and IL-18 in L1210 murine leukemia model. Gene Ther 14: 1181-1187, 2007.

20. Yin C, Dang HN, Gazor F and Huang GT: Mouse salivary glands and human beta-defensin-2 as a study model for antimicrobial gene therapy: technical considerations. Int J Antimicrob Agents 28: 352-360, 2006

21. Harvey SA, Romanowski EG, Yates KA and Gordon YJ: Adenovirus-directed ocular innate immunity: the role of conjunctival defensin-like chemokines (IP-10, I-TAC) and phagocytic human defensin-alpha. Invest Ophthalmol Vis Sci 46: 3657-3665, 2005.

22. Meyerholz DK, Grubor B, Gallup JM, et al: Adenovirusmediated gene therapy enhances parainfluenza virus 3 infection in neonatal lambs. J Clin Microbiol 42: 4780-4787, 2004.

23. Bals R, Weiner DJ, Moscioni AD, Meegalla RL and Wilson JM: Augmentation of innate host defense by expression of a cathelicidin antimicrobial peptide. Infect Immun 67: 6084-6089, 1999.
24. Gaudreault E and Gosselin J: Leukotriene B4 induces release of antimicrobial peptides in lungs of virally infected mice. J Immunol 180: 6211-6221, 2008.

25. Alekseeva L, Huet D, Femenia F, et al: Inducible expression of beta defensins by human respiratory epithelial cells exposed to Aspergillus fumigatus organisms. BMC Microbiol 9: 33, 2009.

26. Krisanaprakornkit S, Kimball JR, Weinberg A, Darveau RP, Bainbridge BW and Dale DA: Inducible expression of human beta-defensin 2 by Fusobacterium nucleatum in oral epithelial cells: multiple signaling pathways and role of commensal bacteria in innate immunity and the epithelial barrier. Infect Immun 68: 2907-2915, 2000.

27. Liu AY, Destoumieux D, Wong AV, et al: Human beta-defensin-2 production in keratinocytes is regulated by interleukin-1, bacteria, and the state of differentiation. J Invest Dermatol 118: 275-281, 2002

28. Kanda N, Tada Y, Shimizu T and Watanabe S: IL-12, IL-23, and IL-27 enhance human beta-defensin-2 production in human keratinocytes. J Invest Dermatol 38: 1287-1296, 2008.

29. Tsutsumi-Ishii Y and Nagaoka I: NF-kappa B-mediated transcriptional regulation of human beta-defensin-2 gene following lipopolysaccharide stimulation. J Leukoc Biol 71: 154-162, 2002.

30. Yoon YM, Lee JY, Yoo D, et al: Bacteroides fragilis enterotoxin induces human beta-defensin-2 expression in intestinal epithelial cells via a mitogen-activated protein kinase/I kappa B kinase/NF-kappa B-dependent pathway. Infect Immun 78: 2024-2033, 2010.

31. Wehkamp J, Harder J, Wehkamp K, et al: NF-kappaB- and AP-1-mediated induction of human beta defensin- 2 in intestinal epithelial cells by Escherichia coli Nissle 1917: a novel effect of a probiotic bacterium. Infect Immun 72: 5750-5758, 2004.

32. Palkowitsch L, Marienfeld U, Brunner C, Eitelhuber A, Krappmann D and Marienfeld RB: The $\mathrm{Ca}^{2+}$-dependent phosphatase calcineurin controls the formation of the Carma1Bcl10-Malt1 complex during T cell receptor-induced NF-kappaB activation. J Biol Chem 286: 7522-7534, 2011.

33. Lavigne JP, Brunel JM, Chevalier J and Pages JM: Squalamine, an original chemosensitizer to combat antibiotic-resistant gramnegative bacteria. J Antimicrob Chemother 65: 799-801, 2010. 